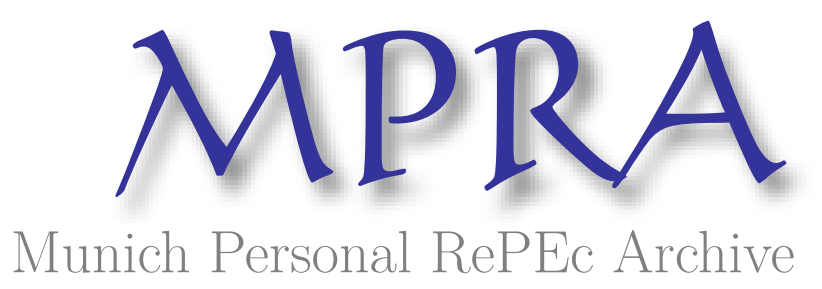

\title{
Contract enforcement and institutions among the Maghribi Traders: Refuting Edwards and Ogilvie
}

\author{
Greif, Avner \\ Stanford University, U.S.A.
}

1 July 2008

Online at https://mpra.ub.uni-muenchen.de/9610/

MPRA Paper No. 9610, posted 19 Jul 2008 07:53 UTC 


\title{
Contract Enforcement and Institutions among the Maghribi Traders:
}

\section{Refuting Edwards and Ogilvie}

\author{
Avner Greif \\ Stanford University, June 30, 2008
}

\begin{abstract}
Edwards and Ogilvie (2008) dispute the empirical basis for the view (Greif, e.g., 1989, 1994, 2006) that multilateral reputation mechanism mitigated agency problems among the eleventh-century Maghribi traders. They assert that the relations among merchants and agents were law-based. This paper refutes this assertion using quantitative and documentary evidence thereby vindicating the position that the legal system had a marginal role in mitigating agency problems in long-distance trade in this historical era. ${ }^{* *}$ Edwards and Ogilvie constantly present legal actions in non-trade related legal cases as evidence for a reliance on the legal system for matters pertaining to long-distance trade. Their criticism of Greif's documentary analysis also fails scrutiny. The claim that merchants' relations with their overseas agents were law-based is wrong.

This paper is based on quantitative analyses of the corpuses containing the hundreds of documents on which the literature relies and a careful review of the documents and the literature Edwards and Ogilvie cite. Their assertion is shown to be based on unrepresentative and irrelevant examples, an inaccurate description of the literature, and a consistent misreading of the few sources they consulted. In particular, their examples for the use of the court are mainly taken from mandatory legal procedures associated with sorting out the assets and liabilities of deceased traders' estates. Such examples do not support the claim that agency relations were law-based. The quantitative analysis reveals that empirical basis for the multilateral reputation view is stronger than originally perceived. This paper also sheds light on the roles of the legal system and reputation mechanism during this period.
\end{abstract}

* I am thankful to Latika Chaudhary, Paul David, Joel Mokyr and Gavin Wright for useful comments.

${ }^{* *}$ This response is concerned with the first version of Edwards, Jeremy and Ogilvie, Sheilagh, "Contract Enforcement, Institutions and Social Capital: The Maghribi Traders Reappraised." CESifo Working Paper Series No. 2254. March 2008. I suggest to download their paper from my home page http://www-econ.stanford.edu/faculty/greifhp.html although it was originally posted at CESifo:

http://www.cesifo-group.org/wp, http://www.cesifo.de/DocCIDL/cesifo1_wp2254.pdf, and SSRN (posted March 19, 2008) http://ssrn.com/abstract=1107801. Downloading from my page guarantees compatibility between their paper and my response. 
The view that multilateral reputation mechanism governed agency relations among the eleventh-century Maghribi traders (Greif 1989, 1993, 1994, 2006) is based on the premise that the legal system lacked the information and enforcement capacity to provide a viable alternative. Edwards and Ogilvie (2008) (henceforth E\&O) challenge the empirical validity of this premise and assert that the documents directly reveal that "the main contract-enforcement mechanism used by the Maghribis [to govern agency relations in long-distance trade] was the legal system" (p. 36). This paper refutes this assertion, highlights the mistakes in E\&O's analysis, reaffirms the empirical basis for the multilateral reputation view, and discusses the role that the legal system played among the Maghribis. The claim that the relations of merchants with their overseas agents were law-based is wrong.

Central to E\&O's assertion that agency relations were law-based is an interpretation of the literature and documentary examples taken from this literature (section 3 ). I begin refuting this assertion using quantitative analyses based on the recently published corpuses of the hundreds of documents on which the literature relies. ${ }^{1}$ These analyses also facilitate a documentary examination showing why E\&O's interpretation and evidence are misleading and their conclusion, therefore, is wrong.

E\&O also claim that the geniza documents do not reflect a multilateral reputation mechanism, that theoretically it could not have prevailed, and that its implications are not observed (sections 4 to 6). Quantitative and documentary analyses establish that each and every one of these allegations is mistaken. The empirical basis for the importance of multilateral reputation proves completely robust. The claim that agency relations in long-distance trade were mainly law-based has no empirical basis.

To illustrate the strength of the quantitative evidence supporting the multilateral reputation view, consider the following. About seventy five percent of agency relations were not based on a legal contract. Less than one percent of the documentary text is devoted to the discussion of any legal action. The fraction of court documents reflecting disputes in agency

\footnotetext{
${ }^{1}$ The labor of various scholars, particularly Professor Moshe Gil $(1983,1997)$ has now placed many trade-related documents in print.
} 
relations is less than eight thousandths of all documents. The ratio of court cases related to agency relations to all agency relations is much lower.

While the quantitative evidence is sufficient to refute E\&O's claims, I also examine the literature they cite, the examples they provide, and their criticism of my documentary analysis. This examination substantiates that E\&O build their case on unrepresentative and irrelevant examples, a consistent misreading of the few sources they present, and a distortion of my and other scholars' arguments. It is quite apparent that they did not sufficiently consult the original sources on which their assertions are based and consistently misread and draw the wrong conclusions from the secondary literature. ${ }^{2}$

In particular, E\&O assume that any documentary evidence for the use of the legal system is an evidence for its use in preventing opportunism by overseas agents. This assumption, however, is false: the majority of legal actions mentioned in the merchant letters are concerned with legal issues unrelated to trade or agency relations. Their examples for the use of power of attorney, the examination of accounts and letters by the court, the use of witnesses to identify the writers of letters, etc., are mainly taken from mandatory legal procedures associated with sorting out the assets and liabilities of deceased traders' estates. Such examples do not support the claim that agency relations were law-based. E\&O mistake legal actions in these non-trade related legal cases as evidence for a reliance on the legal system for matters pertaining to long-distance trade.

It should be clear that this paper is not aimed to present the evidence supporting the multilateral reputation view. Indeed, E\&O do not consider all the evidence indicating that a multilateral reputation mechanism prevailed. The discussion here, however, is confined to demonstrating that E\&O's arguments - even for the evidence they choose to focus on - are unsustained and wrong.

\footnotetext{
${ }^{2} \mathrm{E} \& \mathrm{O}$ seem to suggest parity in accessing relevant sources. "The discussion in this paper is based on the documentary sources ... which are the same as those used by Greif" (p. 8). Yet, they neither study the original documents nor even read Hebrew without which one can not directly access the majority of the published documents. The implications of the implied disparity, I believe, will become apparent.
} 


\section{The Use of the Legal System by the Maghribi Traders}

$\mathrm{E} \& \mathrm{O}$ assert that "the main contract-enforcement mechanism used by the Maghribis [in overseas agency relations] was the legal system" (p. 36). They summarize the alleged empirical basis for this assertion in three statements. (1) "The evidence shows that Maghribi traders made widespread and voluntary use of the formal legal system to enforce their contracts" (p. 37). (2) As a general rule, "business associations between Maghribi traders were based on legal contracts" (p. 12) and (3) the "Maghribi traders regarded it as a matter of course to keep accounts ... and they made use of the courts to establish the veracity of this information" (p. 13).

If confirmed, these generalizations contradict the empirical basis for the view that contract enforcement in agency relations was based on a multilateral reputation mechanism. The empirical basis for the multilateral reputation view is as follows. (1) "Only a few documents indicate that commercial disputes between merchants and agents were brought before a court." (2) "Many, if not most, of the agency relations reflected in the geniza were not based on legal contracts" and (3) due to the asymmetric information inherent in agency relations, "the court was usually unable to verify agents' claims and actions or to track down an agent who had emigrated ... and litigation was expensive and time-consuming" (e.g., Greif 1989, pp. 865-6; 2006, p. 63).

The generalizations advanced by $\mathrm{E} \& \mathrm{O}$ are empirically testable using the corpuses of merchant letters that are the basis for the literature that they cite (as they note on p. 8). These corpuses contain any documents pertaining to the commercial, personal, legal, communal or other affairs of known traders. Gil (1997) contains 745 merchant letters (docs. 102-846) and Gil (1993), vol. III contains 73 merchant letters (docs. 458-530). ${ }^{3}$

1. In contrast to E\&O's claim, there is no evidence "that Maghribi traders made widespread and voluntary use of the formal legal system to enforce their [agency] contracts" (p. 37). (All emphases in this paper were added.)

Merchant letters can shed light on the use of the legal system because about five percent of them refer to a dispute of some kind (Greif 1993 p. 528, 2006, p. 63; Gil 2003, p. 214). Yet, the most comprehensive quantitative study of the geniza (Goldberg 2005) reveals little use of the

\footnotetext{
${ }^{3}$ The latter corpus was collected specifically for Gil's study on Palestine.
} 
legal system. This exciting study is a computerized content analysis of a representative random sample (15 percent) of about 900 documents. ${ }^{4}$ Her data set includes, in addition to Gil's 818 documents, any document (published or transcribed) concerned with a commercial investment in trade. Goldberg finds that "discussion of any legal action - threatening action, sending power of attorney, requesting provision of documents for an upcoming action - account for just over one percent of the material" (2005, pp. 106-7). Based on this observation and an examination of all the documents, she concludes that there was "a low incidence of seeking redress through formal legal channels" (p. 204).

Because the documentary corpuses include all legal documents pertaining to the affairs of known traders, they should contain agency-related court documents, if they exist. This claim is supported by the content of court documents. It was mandatory to rely on the court in matters pertaining to estates and indeed, as detailed below, court documents reflect legal activities concerned with estates. In contrast to the tradition of legal enforcement of inheritance law, there is a long tradition, in the Jewish (and Muslim) legal systems, of leniency in enforcing delinquent debt payment (Gil 2003). It is therefore reassuring that although letters often reflect late payment of debt, only a few legal documents reflect debt disputes. ${ }^{5}$

Examining court-documents also has the advantage of directly revealing what the legal system was used for and relatively clearly reflecting the nature of legal disputes. Accordingly, I examined all court documents (i.e., court cases, contracts, appointments, deeds, testimonies, and wills) found among the 745 merchant letters in Gil (1997). Gil identified and indexed all such documents.

\footnotetext{
${ }^{4}$ Goldberg (2005) uses the software "Nvivo, which allows strings of any length of characters to be coded ... content trees. ... [Goldberg] coded each document by hand. The program will run counts of total characters at any level of a tree" (p. 52). My understanding is that her metric is percentage of characters devoted to the discussion of, in this case, legal actions. Goldberg also found that the traders discussed moral hazard less than legal actions and discussed adverse selection much more. Her interpretation is that reputation mainly mattered in wage setting, and then both in adverse selection and moral hazard.

5 "The only "misconduct" that appears over and over in the documents is late payment of debts. This, however, seems to reflect shortage in liquid assets and was not considered as misconduct" subject to multilateral punishment (Greif 1989, p. 864, fn 33). Gil (2003) similarly notes that "the problem which often troubled creditors was that of delays in the repayment of loans" (p. 297). In my sample of 83 documents, about 32 percent mention debt and its collection. Clay (1997) examines theoretically and historically endogenous different forms of misconduct under a multilateral reputation mechanism.
} 
There are 29 court documents in the corpus, 12 of them are trade-related, and six of these are partnerships and debts contracts and the rest relate to agency relations. Only three court documents reflect disputes involving agency relations (and I will describe them below). ${ }^{6}$ This is four thousandths of the documents (3/745). To verify robustness, I looked for court documents that may have been related to agency disputes (e.g., promissory notes that may have concluded agency disputes). I found three such documents implying that the upper-bound of the share of court documents concerned with agency disputes is less than eight thousandths of the total $(6 / 745)$. Note that each of these three to six court documents discusses only one dispute but most of the other documents discuss many agency relations. Out of the total number of agency relations and transaction, this number of court documents is minuscule. ${ }^{7}$

A random sample of every tenth document in the two corpuses (Gil 1993, 1997) similarly reveals little reliance on the legal system to govern agency relations. Specifically, I examined the content of every tenth document (83 documents). Only one document (Gil 1997, no. 622) mentions a legal dispute involving agency relations among the Maghribis. Significancy, the dispute is one among the three reflected in the court documents. (Specifically, doc. 622, a letter, and doc. 623, a court document, are concerned with the same dispute.) There are additional four documents in which legal actions are mentioned in the context of trade. Three are concerned with disputes with non-Maghribis. (Two are debt disputes with Muslim traders and one is a dispute with a non-Maghribi agent who tried to get a hold of goods sent to another agent.) In only one of these cases a legal action was actually taken. One document mentions a promissory note among Maghribis.

E\&O's claim “that Maghribi traders made widespread and voluntary use of the formal legal system to enforce their [agency] contracts" (p. 37) is unsubstantiated. The 'evidence' that E\&O cite to support the supposed widespread reliance on the legal system in agency relation is actually based on evidence for the use of the legal system in cases unrelated to trade. In many of

\footnotetext{
${ }^{6}$ Gil (1997), docs. 229, 319, 623. Overseas agency relation are those among one trader who handles another's trader's capital or goods in a different location.

${ }^{7}$ On average, the number of agency transactions reflected in a letter is probably more than ten.
} 
these cases the use of the court was mandatory and in all of them the problems of verifiability and enforcement differed from those in agency relations.

In the above sample of 83 documents, there are 16 documents in which legal actions are mentioned out of which 11 are non-trade related and, among them, six are concerned with estates. $^{8}$ Goldberg (2005) similarly concludes, based on the 900 documents she examined, that "most of the legal cases recorded are to settle disputes over the estates of deceased merchants, sorting out the resolution of ownership of the goods and debts he held at the time of his death" (p. 205). The court documents in Gil (1997) reaffirm this conclusion and provide details. About 60 percent of the court documents, 17 out of 29, are unrelated to trade. Four are concerned with private matters (e.g., manumission) and the remaining 13 are concerned with estates of deceased traders. In absolute and relative terms, the most important use of the legal system reflected in the Maghribis' letters is in matters pertaining to estates.

The use of the legal system in cases involving estates was mandatory. Dissolution of estates was a public - not a private - matter because the Jewish (and Muslim) law dictates the division of an estate. Furthermore, the Muslim authorities recognized the right and obligation of the Jewish courts to take care of estates even of non-local Jews who passed away during their stay (Goitein 1971, pp. 394-9). If a Jewish traveler perished at sea, Jewish authorities in the next or final port took care of the estate even if a relative or another Jewish companion were on board (Khalilieh 2006, p. 192). The mandatory involvement of the legal system following the death of one's business associate left him no choice but resorting to the legal system to reclaim or protect his assets. Although it may be that this mandatory use of the legal system facilitated trade, this matter is distinct from legal contract enforcement in agency relations.

The prominence of legal cases concerned with estates apparently eluded E\&O and the word 'estate' does not appear in their paper. Yet, the finding that legal activities mentioned in the documents are mainly to be concerned with mandatory non-trade related matters invalidates the premise of the revealed-preference argument on which E\&O rely. This argument is that "the fact that Maghribi traders incurred the costs of using the legal system ... shows that they regarded it as a valuable mechanism for enforcing long-distance trading contracts" (p. 14). The premise

\footnotetext{
${ }^{8}$ Among these, doc. 232 (Gil 1997) also mentions another unclear legal case.
} 
underpinning this argument is that the Maghribis used the legal system only voluntarily (as E\&O note six time) and only for the purpose of contract enforcement in long-distance trade. If this premise holds, it is appropriate, as E\&O do, to interpret any use of the legal system as an evidence for its use in agency relations in long-distance trade. This premise, as demonstrated above, is false.

Because most of the legal activities mentioned in the documents are unrelated to trade and/or mandatory, it is misleading to present, as E\&O do, any evidence for the use of the legal system as an evidence that it was used in long-distance trade. Caution is required in differentiating between legal activities concerned with trade (and agency relations) and legal activities concerned with traders. E\&O do not exercise such caution and therefore misrepresent the evidence. Similar care should also be exercised in relying on Goitein (1967) and Gil (2003), the two publications which E\&O predominantly cite for support. Goitein (1967) relies on all the geniza documents and discuss all economic activities. His various statements are not necessarily relevant with respect to the Maghribi traders or long-distance trade. Similarly, although Gil (2003) focuses on the Maghribis, his analysis goes beyond trade-related issues.

In addition, E\&O's analysis creates a false impression regarding the nature and use of the legal system by providing inaccurate descriptions of the literature and documentary evidence. To illustrate this point, consider the first two examples that E\&O introduce as evidence for enforcement of contracts in long-distance trade by the Muslim authorities (p. 10). (Focusing on the Muslim court complements the above discussion of the Jewish court.)

E\&O note twice that "according to Gil[2003, p. 318], conflicts between Maghribi merchants also gave rise to situations in which the Muslim authorities sent soldiers to compel the defaulting debtor to render payment" (p. 10). Clearly, enforcing a debt contract, in which it is relatively easy to verify conduct, is no evidence for the role of the legal system in agency relations in which verification is more difficult. In their subsequent reference to soldiers, E\&O implicitly claim that soldiers were used more generally in long-distance trade. "Maghribi traders thus had at their disposal a wide array of formal legal enforcement mechanisms and did not refrain from using them, even if it involved asking the Muslim authorities to intervene by sending soldiers to enforce payment" (p. 15). 
In fact, these statements are misleading. The relevant documents mention neither (1) conflicts among Maghribis, (2) nor legal authorities, (3) or voluntary reliance on the Muslim legal system, (4) or the role of this system in agency relations. E\&O cite page 318 in Gil (2003) which contains a summary and provides no documentary references. In the paper itself, however, Gil twice mentions debt collection by soldiers. In the first instance, he notes that a "crew [of a Muslim ship] delayed acceptance of the [Maghribi trader's] flax, ... [this] caused [the trader] severe financial damage; he delayed payment, and they threatened him and sent soldiers against him" (p. 309). The conflict was not among Maghribis, it was a local dispute, and there is no evidence of a legal process or its voluntary use by the Maghribis.

In the second instance, Gil reports that "a poorly preserved letter ... apparently indicates that the authorities would impose a fine ... of delay in the payment of the check" (pp. 304-5). He stresses (p. 305, fn. 146) the tentative nature of his claim by noting that Goitein read the document differently. Goitein argued that the "check was payable to the order of a government officer" implying that the case is unrelated to trade and probably related to tax payment. Although the original letter (TS 12.281, Gil 1997, doc. 254) is unclear on this point, it leaves no doubt that the issue was un-related to agency relations, the fine was imposed on Maghribis and not on their behalf, and the Muslim legal system was not voluntarily used to resolve a dispute. In any case, generalizing from this "poorly preserved" single evidence on the role of the legal system seems unfounded.

An even larger discrepancy between the evidence and E\&O's interpretation is present in the second example for the role of the Muslim legal system. We are told that "a debt dispute between Maghribi traders could also be 'brought before the Sultan', who evidently also provided formal, public contract enforcement to which Maghribi traders sometimes voluntarily resorted" (p. 10). Clearly, this is a debt-related and not an agency-related case. More significantly, this statement distorts the evidence. E\&O refer to Gil (2003, p. 299) who tells a different story. "A certain b. alShiryāni, who owed his creditors the vast amount of 4,000 dinars [could not pay]. The writer [a Maghribi trader] had also sold this man a cargo of flax ... and was forced to interrupt his business [and delay his departure] ... The entire case was brought before the sultan [of al-Mahdiyya (Tunisia)]" who ruled about the seniority of various claims. 
The vastness of the sum involved and the interruption of trade suggest that this was an extraordinary situation. E\&O's conclusion that this document reflects a regular court providing "formal, public contract enforcement" seems unwarranted. Even more troubling is that Gil does not claim that Maghribi traders approached the court or that the dispute was among Maghribi traders. An examination of the original letter (e.g., Ben-Sasson 1991, no. 83) reveals that E\&O's 'corrections' of Gil are unsubstantiated. The letter says that alnās (אלנאס) brought the case before the Sultan, and this term is often used by the Maghribis to refer to 'merchants' or 'people' in general as distinct from the Maghribi traders. Furthermore, AlShiryāni - judging by his name was a Muslim in which case the dispute was not one among Maghribi traders. Interestingly, although E\&O frequently rely on the documents that Goitein (1973) translated to English, they fail to note that he published this letter (no. 25) and concluded - in his translation and commentary - that AlShiryāni was a Muslim and that 'merchants' (and not specifically Maghribi traders) had approached the Sultan.

Quantitative analyses of the geniza documents clearly reveal no "widespread" use of the formal, legal system for contract enforcement in long-distance trade. The evidence supports my claim that "only a few documents indicate that commercial disputes between merchants and agents were brought before a court” (e.g., Greif 1989, pp. 865-6; 2006, p. 63).

2. The evidence also contradicts E\&O's claim that "the general rule [was] that business associations between Maghribi traders were based on legal contracts" (p. 12). Goitein (e.g., 1967) was the first to point out that the Maghribis did not rely much on business associations based on a legal contracts (hereinafter, 'partnerships') and that their business associations often took the form of 'formal friendship' or 'reciprocal agency.' Two traders, operating in different trade centers provided each other with agency services. The arrangement was voluntary, bilateral, initiated by mutual consent, and could be terminated by either party at any time. Formal friendship involved no legal contracts.

Were business associations among the Maghribis formed through partnerships or formal friendships? The documents unambiguously reaffirm that formal friendship was the main form of business association. Goldberg's content analysis reveals that 75 percent of the text in assignable agency transactions was devoted to formal friendships and only 25 percent was devoted to 
partnerships (Goldberg 2005, p. 84). ${ }^{9}$ The percentage of text is a good proxy for relative use because there is no reason to maintain that the length of the text depended on the form of business association. My guess (in 1989) that about 50 percent of agency relations were not based on legal contracts thus seems to have been too conservative. Be it as it may, Goldberg concludes "this disparity [in content] demonstrates a clear preference among merchants ... for controlling and managing the majority of their investments as individuals" (ibid) by relying on formal friendship.

There is no empirical basis to E\&O's claim that "the general rule" among the Maghribis was to establish agency relations using legal contracts. Business associations based on legal contracts (partnerships) were the exception, not the rule. The evidence also does not support a position that E\&O inaccurately attribute to me. "Greif's claim [is] that the Maghribi traders made no use of the legal system to specify the terms of their business associations" (p. 13). However, the evidence supports the claim I actually made. "Many business associations were not based upon any legal contract" (Greif 1989 p. 864; 2006 p. 63).

Although partnership probably provided marginally better protection against opportunism, partnerships, in general, are not an effective means to discipline overseas agents. ${ }^{10}$ Contract enforcement in agency relations differs from contract enforcement among partners. When a provider of agency services is not a partner, the partnership contract does not protect the partners from embezzlement by the agent. The situation is basically the same when a partner is also the overseas agent. The partner serving as an agent can embezzle from the partnership. Severely restricting agents' choices limit embezzlement but also the agent's ability to take profitable actions. In any case, Maghribi agents had much freedom of action.

The Maghribis seem to have recognized that contract enforcement in agency relations differ from contract enforcement in the relations among partners. In one third of the (long-

\footnotetext{
${ }^{9}$ It is impractical to count friendships and partnerships. Goldberg does not report the percentage that was unassignable.

${ }^{10} \mathrm{~A}$ partner was obliged, if requested, to take a 'partner's oath' upon termination of the contract that he was not engaged in malfeasance or negligence with partnership assets (Goitein 1967, p. 172). A formal friend was not obliged to take such oath. Yet, once an agent accepted a shipment he fell under the Jewish law of agency. This law, and its Muslim equivalent recognized, however, that agency relations had to be based on trust and hence were very lenient toward an agent. (See Gil 2003; Greif 1989, 2006.)
} 
distance trade) partnerships, a partner(s) relinquished the right to legally challenge the partner who would serve as an agent. (I provide more details later.) This implies that even if legal contracts afforded more protection, the share of business associations with the protection afforded with legal contracts was even lower than the quarter by Goldberg.

More importantly, the observation that the Maghribis entered into partnerships while waiving the right to sue the partner who serves as an agent is consistent with the view that reputation-based enforcement prevailed and the mandatory reliance on the legal system when one's business associate passed away. Taking care of a trader's estate was a complicated task given the complexity of business relations. Furthermore, disputes were more likely to arise in estate-related legal cases due to the reduction in the quality of information and the introduction of new actors (trustees and heirs, who were not necessarily traders, and the Jewish and Muslim courts). ${ }^{11}$ Indeed, disputes are reflected in three out of the 13 estate-related court documents in Gil (1997).

A partnership contract was therefore useful in establishing one's financial arrangement with a deceased business association. Formal friends had to rely only on letters and accounts in making their case. ${ }^{12}$ The argument that traders' choice of contractual forms was influenced by their potential post-mortem implications gains further support from the observation that other contractual choices reflect this influence. ${ }^{13}$ In many of the contracts in Ackerman-Lieberman (2007), at least one of the sides declares that his legal obligation binds his heirs. ${ }^{14}$

${ }^{11}$ The Muslim and Jewish inheritance laws differ and one could challenge the Jewish court's ruling.

${ }^{12}$ Obviously, other considerations influenced the choice between partnership and formal friendship. In particular, partnerships were costly to establish and dissolve. The Jewish law requires that all partners will be physically present in signing the contract, but to benefit from agency relations traders had to be apart from each other. Goldberg (2005) conjectured that long-term partnerships were not common because they restricted business flexibility.

${ }^{13}$ See TS 18 J 1, f 10, Gil (1997), vol. 3, doc. 565. An out-of-town Maghribi trader was approached to write a will in which he would specify "what people owe him and what he owes others because he is sick, and if" he perish it would be unknown who owes him and whom he owes money to.

${ }^{14}$ In addition, the Maghribis often left 'conditional divorce' contracts with their wives. The contract freed a wife to remarry in case her husband, the trader, was presumed dead but this could not be legally established 
E\&O's claim that as a "general rule ... business associations between Maghribi traders were based on legal contracts" (p. 12) is clearly wrong and appears to rest not on empirical evidence but largely on their inaccurate reading of the secondary literature. We are told, for example, that "Gil concludes that all Maghribi business associations "were based on a deed formulated by the court"” (p. 12; underline in the original) and are then referred for authority to Gil (2003, p. 274, footnote 2). But what one actually reads in the cited passage is that "all partnerships were based on a deed formulated by the court." Moreover, Gil explicitly recognized partnerships to have been a subset of business associations. ${ }^{15}$

3. The evidence contradicts the claim that the Maghribi traders "made use of the courts to establish the veracity" of agents' accounts (p. 13).

$\mathrm{E} \& \mathrm{O}$ contend to refute my observation that "the court was usually unable to verify agents' claims" (Greif 1989, pp. 865-6; 2006, pp. 63-4). Specifically, they argue that the Maghribi traders used the legal system to establish the veracity of their accounts and they cite Gil (2003 pp. 262-8) as an authority (on page 13, fn. 40). Gil (2003) relies on the 745 documents in Gil (1997) which contains 55 accounts. Yet, an examination of these accounts reveal no direct or indirect sign that the court 'establish[ed] their veracity.' This fact did not escape Gil (2003), who remarked only that the Maghribis kept and exchanged accounts.

E\&O's attribution to Gil a conclusion that he never made would appear to have been offered in lieu of some additional empirical evidence. Indeed, they provide several documentary evidence (pp. 13-4) of cases in which traders submitted accounts and letters to the court, and assert that the purpose of these legal procedures was "the establishment of what both parties have agreed to and what they actually deliver" (p. 13). This assertion, however, is misleading and based on $\mathrm{E} \& \mathrm{O}$ erroneous revealed preference argument. What E\&O neglect to note is that

\footnotetext{
${ }^{15} \mathrm{E} \& \mathrm{O}$ argue (fn. 37) "that Gil uses the term 'partnership' to refer to all forms of business association (see his discussion in the main text of p. 274)." Page 274, however, indicates otherwise. "A comprehensive discussion of matters of partnership, according to the Geniza letters, was included in Goitein [1967, etc.]. He finds that there were four kinds of cooperation: (a) friendship and informal cooperation; (b) partnership ... (c) family partnership; (d) commission and agency." Partnerships is a subset of the "four kinds of cooperation" or business associations. Gil (2003) seems, however, to be sometimes inconsistent in using these terms.
} 
the four out of the five legal cases they present are concerned with estates and the fifth is a legal confirmation of a letter's content. ${ }^{16}$ Such legal cases do not require verifying what agents "actually delivered" and the court does not have to audit the accounts. The court has only validate the authenticity of documents. This evidence therefore does not reveal that the court had the ability to establish the veracity of agents' accounts as necessary for enforcing agency contract.

The literature cited by E\&O relies on corpuses containing documents concerned with traders. But there are also corpuses of court or legal documents that E\&O did not consult, perhaps being aware that these documents are likely to overstate the role of the legal system in contract enforcement. An examination of these sources, however, fails to provide any empirical support for the importance of legal contract enforcement in agency relations, but actually contributes to refuting it.

The corpus published by Ackerman-Lieberman (2007) is particularly important because it provides the first systematic collection of all previously unpublished partnership-related legal documents. ${ }^{17}$ It contains 105 legal documents mentioning partnerships and includes, in particular, the legal documents used by Goitein (1967) on whose work E\&O have relied extensively for examples and generalizations.

About 35 percent of the documents concerned with long-distance trade and about 65 percent deal with industrial and commercial partnerships. The trade-related documents provide no indication that traders used the court to certify the veracity of partnerships' accounts. Most trade-related documents are partnership contracts or notes attesting the dissolution of a partnership (a 'release'). There are only two legal cases that may have pertained to agency relations. ${ }^{18}$ The first is a power of attorney given to an agent who would travel and collect a delayed payment from a former business associate abroad. The second case is that of a merchant

${ }^{16}$ E\&O refer (in fn 41, 42) to Gil (2003), pp. 280, 288-9 who refers to Gil (1997) docs. 312, 632, 633, 732 , and 823 . The discussion in Gil (2003) is only about the legal procedures, not their implications.

${ }^{17}$ See Ackerman-Lieberman (2007), p. 11, fn. 2 for reference to the few other collections of legal documents. I was unable to obtain access to any of them so far. See also Bareket (1998).

${ }^{18}$ Docs. 57 and 78. Due to the time sensitive nature of this paper, I did not have the opportunity to go over the corpus with as much care as I would have liked to. 
who asserted that the agent cheated him, contemplated taking a legal action, although in the end did not. His decision, as I noted (e.g., Greif 1989), probably was due to the difficulty of legally proving opportunism by agents. There is no evidence in this corpus of "widespread" contract enforcement in trade related agency relations.

The content of the partnership contracts also suggests the marginality of the law in preventing opportunism by agents. In a third of the partnership contracts (as I previously noted), merchants relinquished some, and most likely all, their legal recourse in case of dispute with their agents. Specifically, the agent was declared legally 'trustworthy' (נאמן) or 'trustworthy in his words' (נאמן בדיבורו) whose testimony equals that of 'two valid witnesses.' The following statement from a legal document exemplifies such declarations. "I declare him trustworthy like two valid witnesses, so he is not liable for explanations, or an oath or herem setam (an exclusion)." ${ }^{19}$ Legal immunity for a trustworthy witness is a tradition in the Jewish law and the prominent Jewish legal authorities of the period, Hai and Maimonides, held this tradition. ${ }^{20}$

To summarize: There is no empirical basis to support the claim that "the main contract-enforcement mechanism used by the Maghribis [to enforce agency contracts in long distance trade] was the legal system" (p. 36). In making this claim, E\&O avoid systematic analysis of the evidence, misread and draw the wrong conclusions from the secondary literature, distorted the documentary evidence, and presented mandatory legal actions concerned with traders' affair as voluntary legal actions concerned with agency relations in long-distance trade. In contrast to E\&O's claim, agents were rarely brought to court, most agency relations were not based on legal contracts, and accounts' veracity was not verified by the court. The evidence thereby sustains my position that the legal system had a marginal role in agency relations. There was only very "limited legal contract enforceability" in agency relations (Greif 1993 544; 2006, p. 86).

${ }^{19}$ TS 20. 38, a, 11. 26-28, Gil (1997), vol. 4, doc. 823. See also, "He [the agent] is trusted by me with everything he will do, [his testimony] is like that of two valid witnesses, ... and neither I nor anyone on my behalf can bring a complaint or a charge in court [against him]”. TS 20.4, Gil (1997) vol. 4, doc. 821.

${ }^{20}$ See, for example, Maimonides' Mishne Torah, particularly, The Book of Judges, Witnesses Rules, chapter 18. Deuteronomy 19(15) is interpreted to mean that the testimony of two valid witnesses can not be challenged by a larger number of witnesses. Ackerman-Lieberman (2007) maintains that immunity was limited. 


\section{Precondition for Multilateral Punishment}

E\&O also challenge the empirical basis for a multilateral reputation mechanism by contending that (1) its implications are not observed and (2) theoretically it could not have prevailed given the historical context. I return to the first issue in section IV and deal here with the second issue.

E\&O assert that "long-distance communications in the eleventh century were [too] slow" for multilateral punishment among the geographically disperse Maghribis (p. 20).

Communication seems particularly slow if one brings examples, as E\&O do, of communication with remote places. The two examples they present are regarding communication with cities on the 'edge,' the Spanish-Portuguese border and the Algerian Sahara. Furthermore, if communication was very slow, it is unlikely that the legal system could have been as effective as E\&O claim. At the very least, we would expect information flows between individuals whose livelihood depends on fast communication to be at least as fast as information flows between formal legal authorities. If communication was very slow, it is difficult to see how courts established the veracity of a plaintiff's claim of misconduct abroad. If individuals could not exchange accurate information in a timely manner, how could formal legal courts get this information?

In any case, E\&O's claim is historically and theoretically flawed. Historically, the Maghribis quickly coordinated a successful embargo on Sicily (Greif 1994, p. 938).

Theoretically, multilateral reputation among geographically disperse traders does not require fast communication. It only requires that information travels sufficiently fast relative to the eventual sanctions. Multilateral punishment among the Maghribis was a means to achieve that. ${ }^{21}$ Whether multilateral punishment prevailed is an empirical, not a theoretical, question.

E\&O provide only one piece of empirical evidence to support their claim that information was too noisy to enable multilateral punishment. They argue that, given the noisy information,

“it is not surprising that Khalluf b. Musa in Palermo, writing to Yeshu'a b. Isma'il in Alexandria, said that 'had I listened to what people say, I never would have entered into a partnership with you'. Khalluf had clearly not regarded the

\footnotetext{
${ }^{21}$ Moreover, a Maghribi trader typically served as both an agent and a merchant ('principal') which increased the sanctions that can be imposed on him. Greif (1993, 1994, 2006).
} 
unfavourable information circulating about Yeshu'a as being solid enough to prevent the formation of their partnership" (p. 22, and the reference is to Goitein, 1973, p. 121).

E\&O conclude that my discussion of this letter failed to "consider the broader implication of this remark, which is to cast fundamental doubt on the very existence of multilateral punishment" ( $p$. 22).

Yet, this conclusion is dubious at best given that the unfavorable information was, most likely, about performance, rather than about conduct. Yeshu'a complained to Khalluf that he was unable to sell their partnership's goods in the Egyptian countryside. Khalluf, the senior partner, responded by saying "did I not advise you not to sell there even for one penny? ... from this blessed undertaking of yours only losses came to me: 'Had I listened to what people say, I never would have entered into a partnership with you"' (Goitein 1973, p. 121). Given that Khalluf is discussing performance and not conduct, it would not be unreasonable to suppose that the information he ignored had also been about performance.

Indeed, in discussing this case (Greif 1989, p. 871), I had drawn attention to the fact that "the writer, ... was disappointed with his partner's performance." ${ }^{22}$ But rather than referring to that passage in the 1989 publication that $\mathrm{E} \& \mathrm{O}$ have cited so extensively on other points, their reference here (p. 23, fn. 66) is to the discussion of this document in Greif $(2006$, p. 82). Unfortunately, in the latter publication the document is erroneously referred to in connection with the way in which the Maghribi dealt with accusations of cheating. That error may have contributed to E\&O's neglect of the doubts that properly should surround the nature of the prior actions by Yeshu'a, about which Khalluf remained too sanguine. Anyhow, this case is hardly sufficient to "cast fundamental doubt" on the "existence of multilateral punishment."

E\&O also claim that informational 'inaccuracies' and principals' ability to 'extort' money from agents render a multilateral reputation mechanism impossible. This ranting is a red herring. Models are not means to replicate every aspect of reality but to highlight causal mechanisms and facilitate inquiries. I discussed the robustness of my analysis to imperfect monitoring, strategic manipulation of information, and opportunism by merchants toward their

\footnotetext{
${ }^{22}$ The focus of my discussion of this document was that the letter reveals "the linkage between past relations with one merchant and future relations with another."
} 
agents (e.g., 1993, pp. 582-3; 1994, p. 12; 2006, p. 82). Proving that I was wrong requires more than alleging otherwise and quoting letters indicating that the Maghribis communicated and evaluated information as is required for the operation of a multilateral reputation mechanism.

E\&O discussion also fails to do justice to the literature and the historical reality it seeks to present by ignoring the clear evidence of the legal system's limited efficacy as a mechanism for enforcing agency relations in long-distance trade. We know, for example, that courts' limited geographical jurisdiction enabled people to evade "their obligations toward their families, or creditors, or communities by fleeing to another country" (Goitein 1967, p. 69). In such circumstances multilateral reputation mechanism can be effective. Future reward, conditional on past conduct, is an effective incentive device when people can escape punishment.

More generally, asymmetric information, corruption, slow communication, and limited enforcement ability implied that using the legal system was a costly, uncertain, and risky endeavor (Goitein 1967, 1971; Greif 1989, 2006). ${ }^{23}$ One way to illustrate the concrete empirical realities underlying this broad and rather abstract conclusion is to describe the three court documents in Gil (1997), which, as discussed above, are concerned with agency disputes.

One case (doc. 623) suggests that using the court was very costly. A partner who served as an agent for the partnership repeatedly promised to pay the merchant for 10 years until he approached the court, probably deciding that the problem was no ordinary case of debt collection. ${ }^{24}$ It seems that he was willing to pay a heavy price to avoid approaching the court. Another case (doc. 629) reveals a corrupt Muslim legal system. A trader's brother who had served as his agent, borrowed money for his failing alchemy business. Eventually, the Muslim authorities confiscated the trader's goods to pay the debt. The brother escaped but later returned, bribed the authorities, obtained and embezzled the trader's goods. The trader sued his brother in the Jewish court. We don't know the end of this drama.

The last case (doc. 319) highlights the role of the court in mediating conflicts rather then in enforcing contracts: after a few court hearings, a compromise was proposed by community

\footnotetext{
${ }^{23}$ Gil (2003) emphasizes the use of the legal system but does not differentiate between the 'contract' to be enforced (e.g., agency, debt, partnership, estate) and the efficacy of the court in that role.

${ }^{24}$ Obviously, the multilateral reputation mechanism failed in this case, as one might expect to happen from time to time.
} 
leaders. The court seems to be a mediator that complements the multilateral reputation mechanism rather then an independent enforcer in agency relations. Other evidence suggests that this was the case. In a dispute leading to a premature dissolution of a partnership, for example, the court's record literally declares that the "elders are mediating the situation" (AckermanLieberman 2007, no. 52).

\section{Documentary Evidence Reflecting Multilateral Reputation}

E\&O state that "not a single empirical example adduced by Greif shows that any 'coalition' [in which multilateral punishment prevailed] actually existed" (p. 43). Had they looked more carefully at these documents, they could see the evidence for themselves. To demonstrate this I focus here on the first and most elaborate of the documentary examples that E\&O examined. This will provide a 'single' evidence, and will keep the discussion relatively short while entering into enough of the details to exhibit the flaws in E\&O's documentary analysis on this point, as on the others that have already been examined.

This example concerns a letter sent in 1055 from Abun b. Zedaka (Jerusalem) to another Maghribi trader, 'Hayyim ben 'Ammār. ${ }^{25}$ I argued that Abun "was accused (although not charged in court) of embezzling the money of a Maghribi trader. When word of this accusation reached other Maghribi traders, merchants as far away as Sicily cancelled their agency relations with him" (Greif 1989, pp. 868-9; cited in E\&O, p. 25). If this summary is correct, the letter reveals the importance of multilateral reputation.

But E\&O assert that my summary is wrong, and, indeed, they say that there are six mistakes in that one sentence! When these alleged mistakes are corrected, the letter supposedly reveals legal enforcement and bilateral reputation mechanism - or so it is claimed. Specifically, E\&O argue the following (in which I use italics to mark their 'corrections' of my alleged mistakes): Abun was accused of embezzling money from a non-trader and of owing money to the authorities. He had no business relations with 'Hayyim, word of this accusation reached only as far as Egypt and nobody but his close associates responded. Finally, Abun was charged in

${ }^{25}$ TS 13 J 25.12. First transcribed and translated to Hebrew by Gil (1983), vol. 3, doc. 497. Also published by Ben-Sasson (1991), doc. 69. Gil (1997), vol. 1, p. 583 dated, without explanation, the dispute as occurring in 1064. It may be a typo and it is immaterial to my argument. 
court. To substantiate their argument, E\&O say they quote the letter "in full to demonstrate precisely what evidence it contains" (p. 26), discuss the evidence, and refer to scholarly work that they contend support their analysis. Let us, however, consider the details.

Was Abun accused of embezzling the money of a Maghribi trader as I claim? E\&O argue that Abun mentioned in his letter that he was accused of cheating a 'Maghribi gentleman,' not a trader. Yet, Abun was not writing in English. In the letter itself, Abun used the term alsheikh (אלשיך) and the Maghribis commonly employed this term when addressing an important trader. ${ }^{26}$ Indeed, in his letter Abun used this term with respect to two known traders.

The quotation from the letter that E\&O provide, however, does not show these uses of the term alsheikh because, their statement about full quotation notwithstanding, their quotation omitted forty three documentary lines from the original letter. ${ }^{27} \mathrm{E} \& \mathrm{O}$ translated the letter from Gil's Hebrew text (1983, vol. 3, doc. 497) and he presents, in Hebrew letters, both the transcribed document and its translation including the lines they do not quote. The latter, however, are informative about Abun's case. They contain information relevant to establish that (1) he cheated a trader, and, as discussed below, that (2) he was subject to multilateral punishment and that (3) he and 'Hayyim were business associates prior to 1055.

Reading Gil carefully would have spared E\&O from making another dubious and misleading claim, in asserting that Abun was "accused of ... owing money to the authorities" (p. 26). The original, unlike their translation, has 'authority' in singular and not 'authorities' in plural (סלטאן, which Gil translated as שלטון). But Gil (1983, vol. 3, p. 220, n. 14) explains that most likely the meaning here is the 'Authority', namely, God. The statement should not be taken literally but as a metaphor. This interpretation appears in Gil's commentary on the letter, which E\&O (page 25, fn. 85) refer to, remarkably, as supporting their entirely different reading of the passage.

E\&O go on to claim that "the letter does not support Greif's claim that Maghribi traders as far away as Sicily cancelled their agency relations with Abun" (p. 28). They argue that the

\footnotetext{
${ }^{26}$ For documents in which Abun addressed other known traders as sheikhs see, for example, TS 8.257, Gil (1983), doc. 502, 1. 1; TS 12.279, ibid, doc. 498, a, 1. 1.

${ }^{27}$ The missing lines are all the introductory lines, the concluding lines, and the lines written on the margins.
} 
only connection to the island is that the recipient, 'Hayyim, was called, 'al-Madīn̄', 'from Palermo' (Sicily) and proceed to note, based on Goitein (1967), that a toponym like that often reflects a family's place of origin and that Gil (1983) argues that 'Hayyim was from Alexandria.

Be that as it may, Moshe Gil subsequently corrected his 1983 interpretation when further letters made it unmistakable that 'Hayyim's place of residence was Palermo (Sicily), and not Alexandria. Indeed, Gil (1997) himself published several letters (vol. 4, no. 648-659) revealing that 'Hayyim was a prominent merchant in Palermo where his father and two brothers also lived. Most likely, he had been in Palermo in 1055 when Abun sent the letter to him. The geniza contains two letters he sent from Palermo, one in 1055 and the other in $1056 .{ }^{28}$ My MA thesis (Greif 1985), written under the supervision of Professor Moshe Gil, notes that 'Hayyim operated in Palermo and Gil (1997, vol. I, pp. 582-4) and Ben-Sasson (1991, p. 292) have concurred.

Furthermore, 'Hayyim and Abun were business associates prior to 1055, despite E\&O's (p. 28) contrary contention that "Abun describes Hayyim as a 'rival' and a 'mediator', not a business partner." Yet, on the lines of the document that E\&O did not produce in their critique, Abun complained that because 'Hayyim had known him before and had business relations with him, he should have waited to learn more prior to reacting against him (b, right margin, lines 11$18)$.

Next E\&O contend that the letter provides "no evidence of multilateral punishment" (p. 28). "The only person mentioned as having cut off contact with Abun is Naharay ... The letter mentions no other merchants" (p. 28). This statement completely ignores Abun's vivid description of the general hostility he faced in Jerusalem. But there is additional, more subtle evidence in the letter that goes unrecognized in E\&O's analysis. Among the Maghribis, exchange of letters was a public matter. Sending a letter to another trader amounted to publically announcing willingness to establish agency relations. ${ }^{29}$ To find whether merchants in general ceased their relations with Abun, one needs to look for evidence regarding Abun's correspondence.

\footnotetext{
${ }^{28}$ TS 20.122 and ENA NS 2, f. 30, Gil (1997), doc. 651, 650. Gil dated these letters (which, as customary among the Maghribis specify only the day and month on which they were written). The timing of the 1055 letter is uncertain.

${ }^{29}$ For a nice exposition see Goldberg (2005), section 3.6.
} 
Abun mentioned that three merchants refused to communicate with him and his statement reveals that they were not the only ones. First, Abun noted that 'Hayyim is "being ashamed by receiving letters from" him. ${ }^{30}$ Second, he complained that Khalaf ben Salama did not respond to letters sent by him and his brother-in-law - a complaint that appears in lines (a, lines 41-2) of the document that were not quoted by E\&O. Most revealing is Abun's discussion of Naharay ben Nissim (from Fustat).

"I was amazed at R. Nahray, ... for not answering me. One may excuse him, because he does not want to risk the public exposure of an answer. All I want is for him to read my letters when they arrive, even if he does not want to take the risk of answering them" (a, lines 23-25).

Clearly, traders other than Naharay took notice of who was writing to Abun and disapproved of doing so. Abun faced general hostility and traders as far as Sicily ceased or refused to initiate relations with him. Indeed, the fact that his letter was found in Fustat reveals that the traders did not forward it to Sicily. ${ }^{31}$

In E\&O's translation of the letter, the subtlety of the issue was entirely obscured. They render the sentence (indented above) as "Naharay might be forgiven for he does not want to risk censure in my response. All I ask is that Naharay gets the letters and reads them, even if he does not wish to reply to them.." While their deviation from Gil's translation may seem minor, it is critical: nuances matter, especially in an interpretation of an ancient document. It is important to know the context and the fine differences in language. In this case, the social context - and the multilateral response - get lost in E\&O's translation.

Was Abun ever charged in court? There is no evidence in the letter of an impending court case. Yet, the letter suggests that Abun's opponents may have approached the Muslim court, probably to take advantage of the differences between Jewish and Muslim inheritance laws. Furthermore, the person who informed 'Hayyim about the accusations had heard them in the "court of the Head" (of the Yesihva that served as a court of law and a place of higher learning).

\footnotetext{
${ }^{30}$ Abun also requested 'Hayyim to send his regards to "all our friends, the Maghribi travelers, each one by name" (b, line 39). This unusual request suggests that Abun was subject to multilateral response.

${ }^{31}$ In TS 13 J 25, f. 12, Gil 1983, vol. 3, no. 497, Abun requests Naharay (Fustat) to forward a letter to Alexandria, to 'Hayyim.
} 
We don't know whether the informant heard a rumor or a formal legal complaint. In any case, the letter contains no indication that in 1055 Abun was legally accused. Moreover, the letter clearly indicates that Abun was concerned about traders' responses, not legal predicaments.

My analysis of this letter in 1989, therefore, was exact. ${ }^{32}$ Abun was sanctioned by Maghribi merchants from as far as Sicily after he was accused of embezzling the money of another trader. It is, in fact, rather amazing that it is possible to reconstruct such an informative picture of eleventh century dispute. The picture is, of course, not as clear as one would hope for. Yet, what is transmitted loud and clear by this document is the operation and effectiveness of collective punishment.

The document does not reflect "collective punishment by the entire Maghribi community" but E\&O's conclusion that "we must therefore reject" the multilateral reputation view (p. 42) is unsustainable. The essence of this view is that multilateral response sufficiently increases the cost of misconduct beyond that possible under bilateral reputation mechanism. The formal model of collective punishment by all the traders is used to expose causal relations and generate predictions in obviously more complex reality. The point is that in this reality, reputation within a social group mattered. Empirically, even if we were to observe that an agent was not hired by all the traders following misconduct, we can not directly observe if a particular trader did not hire him because of the mis-conduct or irrespectively of it. We can not rely on direct documentary evidence alone in evaluating whether multilateral reputation mattered.

More generally, it is misleading to argue that the lack of 'smoking gun' documentary evidence invalidates the multilateral reputation view. ${ }^{33}$ The lack of such evidence, after all, is what the theory predicts. Punishment is off-the-equilibrium path and rare events are not likely to appear in the historical documents some 900 years later. In seeking direct documentary evidence, the most one can hope to find in "the geniza [is]... evidence on various aspects" of multilateral reputation mechanism (Greif 1989, p. 868). Indeed, this is what we find.

\footnotetext{
${ }^{32}$ This was prior to the publication of many of the works that I have cited here, but at the time I was relying upon the original documents.

${ }^{33} \mathrm{E} \& \mathrm{O}$ claim to the contrary is equivalent to arguing, for example, that because there was no nuclear confrontation during the Cold War, the threat of nuclear response could not have contributed to preventing a conventional war.
} 
Accordingly, in evaluating whether the expectations for multilateral punishment influenced behavior, direct evidence is only one component of a broader empirical strategy on which I elaborated elsewhere (Greif 2006).

Ironically, E\&O have charged that I was careless in my reading of the document. Yet, even in representing what I have written, they exhibit a surprising degree of carelessness. In one letter, a trader wrote to another that 'if your handling of my business is correct, then I shall send you goods.' Commenting on this, I claimed that "conditioning future relations upon past conduct - the essence of reputation mechanism - is well reflected here" (Greif 1989, p. 869). In other words, I claimed that this letter reveals the importance of reputation (and not multilateral reputation). E\&O (p. 24, fn. 67), nevertheless invoke my discussion of this letter to support their contention that "a number of the cases cited by Greif as providing evidence of the existence of a coalition [multilateral reputation] in fact simply show the importance of reputation" (p. 24). They provide only one additional (and similarly unfounded) example for such 'cases. ${ }^{34}$

E\&O claim that "not a single empirical example adduced by Greif shows that any 'coalition' [imposing multilateral punishment] actually existed" (p. 43). The discussion of Abun's letter indicates that this claim is wrong. This claim is based, similar to the discussion of other documentary evidence, on uninformed, incorrect, and misleading documentary analysis. The evidence of multilateral reputation is so clear that even E\&O (p. 36) are led to concede that among the Maghribis "a form of collective punishment ... does appear to have been used" ( $\mathrm{p}$. $36){ }^{35}$

\section{Did the Maghribis have Collectivist Cultural Beliefs?}

Based on their incorrect reading of the literature and evidence, however, E\&O

\footnotetext{
${ }^{34}$ This is a letter reporting that "the buyers refused to pay the agreed price. Eventually the buyers paid, solely out of fear of losing their reputations. As the seller wrote, 'we were lucky...if not the honor...we wouldn't have received a thing...."'(Greif 1989, p. 670). E\&O claim that this reflects bilateral reputation. Yet, had the 'honor' been only between the seller and buyer, there would not have been a problem to begin with.

${ }^{35}$ We read that traders are worried about their 'honour' (p. 24) and what the 'big and small say' about them (p. 26). Behavior is conditioned on news about others' conduct (p. 26) and when the news are bad, one complains that 'letters... have come here to everyone and my honor has been disgraced" (p. 30).
} 
immediately go on to insist that the Maghribis' form of collective punishment was "no different from that practiced in many other commercial contexts before and since" (p. 36). Moreover, they argue, in contrast to my claim, that the Maghribis and their contemporaneous Italian traders were no different in the extent of their collective punishment. This similarity is said to manifest itself in the facts that members of both groups established 'Italian type' family firms (p. 41) and neither was a 'close-knit' group in matters pertaining to agency relations (subsection 4.2). ${ }^{36}$ This allege similarity between the Maghribis and Italians, however, did not exist.

Theoretically, bilateral reputation provides merchants with stronger incentive than multilateral reputation to pool capital on a permanent basis (e.g., Greif 1994, 2006). I argued that the establishment of 'family firms' that pooled capital on a semi-permanent basis among the more individualistic Italians, but not among the Maghribis, is consistent with this theoretical insight (e.g., Greif 1994, 1996; these 'firms' were legally partnerships).

The 'empirical basis' for E\&O's assertion that the Maghribis had 'Italian-style' firms to the same extent as the Italians is taken from the secondary literature, with the work of Goitein (1967, pp. 180-3) in particular being cited. We are told that there were partnerships among family members, some perpetuated for a long time, and that these were labeled by scholars as 'family businesses' or 'family firms.' Yet, Goitein concludes the very discussion to which E\&O referred by saying (in a line they apparently overlooked) that the "general impression conveyed by the Geniza records is that the members of a family usually worked together, but preferred to keep their accounts separate. ... Complete and long-range pooling of resources ... seems to have been the exception rather than the rule" (1967, p. 183 and also Goitein 1973, p. 13). As we have seen, Goldberg similarly concluded, based on the now available larger corpuses, that the

\footnotetext{
${ }^{36}$ In this section, E\&O also argue that I mistakenly have attributed the decline of the Maghribi traders to their inferior institutions rather than the naval and military rise of the Italians. But, what I actually wrote was that "the Maghribis operated in the Mediterranean during the eleventh century until the Italian naval and military supremacy drove out the traders from the Muslim world" (Greif 1993, p. 536). More generally, see my discussion (particularly in Greif 1994, 2005, 2006) on the complexity of the interrelations and implications of various contract enforcement institutions.
} 
Maghribis had "clear preference" for "controlling and managing the majority of their investments as individuals" $\left(2005\right.$, p. 84). ${ }^{37}$

Theoretically, multilateral reputation mechanisms reduce gains from hiring outside the group thereby limiting inter-group agency relations and perpetuating the group (e.g., Greif 1989, 1994, 2006). ${ }^{38}$ I have claimed that "evidence of business association between Maghribi traders and non-Maghribi traders (Jewish or Muslim) is rare" and 'agency relations were established within a well-defined sub-group of the Jewish community" (Greif 1989, p. 877; 2006, p. 77). Systematic analyses of the geniza documents indeed reveal few non-Maghribi traders and even fewer agents. Only two Muslims were among the 97 traders associated with Naharay b. Nissim who was the most important Maghribi trader in Egypt in the late eleventh century (Greif 1994, p. 930). Three partnerships with one Muslim partner each are mentioned in the corpus of 105 legal documents regarding partnerships (Ackerman-Lieberman 2007). These partnerships, however, were industrial and unrelated to overseas trade.

In contrast, E\&O claim that there were "numerous business associations between Maghribis and non-Maghribis" (p. 19). They note that "according to Goitein [1967], on whom Greif relies heavily for much of the rest of his evidence, partnerships between Jews and Muslims were nothing exceptional." From this one would not understand, as I discussed above, that Goitein's statement is based on his study of all the Geniza documents and not the subset reflecting the operation of the Maghribi traders. Moreover, he is referring here to all Jews and not just the Maghribis and to all partnerships, not only to those involved in (long-distance)

\footnotetext{
${ }^{37}$ Much of E\&O discussion here is irrelevant. "Perhaps the greatest importance of the [trader] Ibn 'Awkal correspondence, .... lies in the detailed picture that it gives of the organization of a medieval business house which was prominent long before [a list of Italian firms]" (Stillman 1973, p. 83). This sentence says nothing about this organization. We know the Maghribis came first. We also know, but not reminded by E\&O that this Maghribi business house did not last beyond the life of Ibn 'Awkal. It was not a permanent organization unlike the Italian family firms.

${ }^{38}$ Weaker incentives to hire non-group members does not imply no such hiring. It only implies less hiring than that under bilateral reputation mechanism. Similarly, multilateral reputation mechanism does not, as E\&O assert, require "that Maghribis formed business associations for long-distance trade only with other Maghribis" (p. 16). It requires only that the value of group membership is sufficiently high in equilibrium given the number of non-group agents. E.g., Greif 1993, 1994, 2006.
} 
trade. ${ }^{39}$ But above all, the quote is a sleight of hand in that it replaces agency relations between Maghribis and non-Maghribis (Jews and Muslims alike), which were the subject of my work, to those between the Maghribis and Muslims. Why did the Maghribis rarely establish agency relations with non-Maghribi Jewish traders "although [in other matters they] integrated into existing Jewish communities" (Greif 1989, p. 862)?

Specifically, the core of this disagreement arises from the dubious nature of the evidence E\&O adduce to buttress their argument. E\&O avoid any systematic, quantitative evidence and instead select a few examples that suit them. Once examined with care, however, even these examples reveal only a few non-Maghribi agents. Stillman (1974, p. 195) is cited (on page 17, fn. 50) as saying that a "whole army of Jewish and Muslim agents" served a particular Maghribi trader. But when the primary documents (published in Stillman 1970) are examined, it turns out that only three individuals with Muslim names in this 'army' were identified, and it is far from clear that two of them actually were agents. Stillman (1973, p. 23) is then invoked (on p. 17, fn. 51) as having said that the Maghribi trader in question was "so accustomed" to "doing business with Muslim agents that he employed at least one scribe who could correspond with them in Arabic"; whereas Stillman actually speculated that "perhaps he kept Muslim secretaries too" (1973, p. 23).

Gil (2004, p. 687) is cited to have described a Maghribi trader "engaged in business dealings with Christian merchants in Alexandria around 1030." But the case is not strictly pertinent, since the issue here is not 'business dealings' but 'agency relations.' Moreover, the original document does not even mention 'business dealings.' In response to a question, an agent reported that Christian merchants were on a particular ship. Significantly, unlike other passengers reported to be on that ship who were individually named, the Christian merchants are mentioned as a group. ${ }^{40}$ More disturbing still is the fact that in focusing on one documentary example provided by Gil, E\&O (p. 16) may have conveyed the misleading impression that his position is in agreement with their contention that the Maghribis were not a "stable and

\footnotetext{
${ }^{39}$ Recall that in Ackerman-Lieberman (2007)'s corpus of court documents, only the industrial partnerships involved Muslim partners.

${ }^{40}$ BM Or 5542, f. 220, Gil (1997), vol. 2, doc. 169.
} 
well-defined group." Gil has expressed quite the opposite view, however, writing: "in fact, the merchants who wrote the letters we have before us were a separate and well-defined group among the Jewish population, as well as - understandably — among society in general, including Muslims and Christians" (Gil 2004a, p. 151). ${ }^{41}$

E\&O fail to produce a single piece of evidence indicating that the Maghribis had “numerous," trade-related business associations or agency relations with non-Maghribis . In particular, only a handful of non-Maghribi agents are mentioned in the documents and this observation is informative particularly because the Maghribis extensively interacted with nonMaghribis in other matters.

\section{Concluding Comments}

There is no empirical support for E\&O's claim that the Maghribis made a "widespread and voluntary use of the formal legal system to enforce their [agency] contracts" (p. 37). The evidence vindicates my position that

"many, if not most, of the agency relations reflected in the geniza were not based on legal contracts. Only a few documents indicate that commercial disputes between merchants and agents were brought before a court, and the operation of the court in these cases seems to have been expensive and time-consuming" (e.g., Greif 2006, p. 63; 1989, pp. 865-6).

The conclusion that "the legal system failed to provide a framework within which agency relations could be organized" (Greif, 1989, p. 865) among the Maghribis is appropriate. It is reassuring to note that the now available collections of documents quantitatively indicate that the empirical basis for reputation mechanism is even stronger than originally thought.

\footnotetext{
${ }^{41}$ E\&O also note that "to overcome the problem of traveling on the Jewish Sabbath, it was standard practice for Maghribi traders to confine overland shipments to Muslim 'business friends"” (p. 17). Goitein (1967, p. 281) is cited as an authority although he notes there that overland travel was rare and finding a Muslim carrier was challenging. "The relative paucity of Geniza material about overland travel [reflects that Jewish travelers] ... were prevented... to travel on Saturdays... shipments, when going over a desert route at all, were confined to Muslim business friends ... It was not always possible to find a traveler prepared to transport other people's shipments. Even in the exceptionally large caravan ... referred to above, ... he [a Jewish trader] was unable to ship a package" (Goitein 1967), pp. 280-1.
} 
My analysis highlighted the role of multilateral reputation mechanism in curtailing opportunistic behavior by overseas agents but it abstracted from various issues, such as those related to the complementary role of the legal system and the governance of different transactions by distinct institutions. Similarly, much is yet to be learned about how merchants and agents were actually matched and agents' capabilities influenced their remuneration (Goldberg 2005 particularly focused on the latter issue), intra-group networks and divisions, training, and the impact of differences in cohort and business needs. It would also be useful to better understand the broader institutional complex that created the conditions amenable to foster long-distance trade, the inter-relationships among the institutions of the Maghribis and the broader Jewish and Muslim communities, and the extent to which the Maghribis' institutions also prevailed in these communities.

In any case, the assertion by $\mathrm{E} \& \mathrm{O}$ that the institutional foundations of long-distance trade have always been identical and followed the European model is simply untenable. An appreciation for the diversity of institutional bases for markets and growth is one of the central lessons of economic history. $\mathrm{E} \& \mathrm{O}$ assert that culture is neither a cause nor an integral part of this diversity. Yet, development policies predicated on the idea that culture and institutions are independent have repeatedly proven futile and it is becoming increasingly clear that the boundaries between culture and institutions are blurred and the two are dynamically intertwined in processes of economic development (e.g., Greif 1997, 2005, 2006). The challenge is to identify the causal mechanisms influencing the dynamic inter-relations through which culture, institutions, and economic outcomes co-evolve.

Similarly, E\&O assert that only a minimal level of cooperation can be sustained in the absence of legal penalties. This is a bold claim, which, fortunately, is probably mistaken. Institutions based on multilateral reputation prevailed in the past and are still common in both developed and developing economies. These reputation-based institutions differ, however, in their relative importance, details, dynamics, and inter-relationship with coercion-based institutions (Greif 2005). Furthermore, the static and dynamic welfare implications of specific institutional complexes are neither always positive, nor well understood or constant over time, space, and situations (Greif 1994, 2005, 2006). Advancing our understanding of these complex 
issues, however, requires scholarly work of considerably greater depth, sophistication, and care than have been exhibited in E\&O's paper. 


\section{References}

Ackerman-Lieberman, Phillip Isaac. 2007. A Partnership Culture Jewish Economic and Social Life Seen Through The Legal Documents of the Cairo Geniza. Phd Dissertation. Princeton University.

Bareket, E. 1998. 'Books of Records of the Jerusalemite Court from the 'Cairo Geneza' in the first half of the eleventh-century [in Hebrew]. Union College Annual, Vol 69, 228-282.

Cincinnati: Hebrew Union College.

Ben-Sasson, Menahem. 1991. The Jews of Sicily, 825-1068. Hebrew and Judeo-Arabic. Jerusalem: Ben-Zevi Institute.

Clay, Karen. 1997. "Trade Without Law: Private-Order Institutions in Mexican California." Journal of Law, Economics, and Organization, Vol. 13(1): 202-31.

Edwards, J. and S. Ogilvie, 2008. "Contract Enforcement, Institutions and Social Capital: the Maghribi Traders Reappraised.” Cesifo Working Paper No. 2254

Gil, Moshe. 1983. Palestine During the First Muslim Period (634-1099) [in Hebrew and Arabic]. Tel Aviv: Ministry of Defense Press and Tel Aviv University Press.

Gil, Moshe. 1997. In the Kingdom of Ishmael [in Hebrew]. 4 vols. Tel Aviv: Tel Aviv University.

Gil, Moshe. 2003. "The Jewish Merchants in the Light of Eleventh-Century Geniza Documents." Journal of the economic and social history of the Orient, 46(3), pp. 273-319.

Gil, Moshe. 2004. Jews in Islamic Countries in the Middle Ages. Leiden: Brill

Gil, Moshe. 2004a. "Institutions and Events of the Eleventh Century Mirrored in Geniza Letters (Part I)." Bulletin of the School of Oriental and African Studies, 67(2), pp. 151-167.

Goldberg, Jessica. 2005. Geographies of Trade and Traders in the Eleventh-Century Mediterranean: A Study Based on Documents from the Cairo Geniza. Phd Dissertation. Columbia University.

Goitein, S. D. 1967. A Mediterranean Society: The Jewish Communities of the Arab World as Portrayed in the Documents of the Cairo Geniza, Vol. 1: Economic Foundations. Berkeley / Los Angeles: University of California Press.

Goitein, Shelomo Dov. 1971. A Mediterranean Society: The Community. Los Angeles: University of California Press. 
Goitein, S. D. 1973. Letters of Medieval Jewish Traders. Princeton, NJ: Princeton University Press.

Greif, Avner. 1985. "Sicilian Jews during the Muslim Period (827-1061)" (in Hebrew and Arabic). M.A. thesis, Tel Aviv University.

Greif, Avner. 1989. "Reputation and Coalitions in Medieval Trade: Evidence on the Maghribi Traders." Journal of economic history, 49(4), pp. 857-82.

Greif, Avner. 1993. "Contract Enforceability and Economic Institutions in Early Trade: The Maghribi Traders' Coalition.” American economic review, 83(3), pp. 525-48.

Greif, Avner. 1994. "Cultural Beliefs and the Organization of Society: A Historical and Theoretical Reflection on Collectivist and Individualist Societies." Journal of political economy, 102(5), pp. 912-50.

Greif, Avner. 1996. On the Study of Organizations and Evolving Organizational Forms Through History: Reflection from the Late Medieval Family Firm." Industrial and Corporate Change, vol. 5 (2): 473-501.

Grief, Avner. 1997. "Contracting, Enforcement, and Efficiency: Economics beyond the Law." In Michael Bruno and Boris Pleskovic (eds.), Annual World Bank Conference on Development Economics, 239-66. Washington, DC: World Bank.

Greif, Avner. 2005. "Commitment, Coercion, and Markets: The Nature and Dynamics of Institutions Supporting Exchange," in the Handbook for New Institutional Economics. Edited by C. Menard and MM. Shirley. Chapter 28.

Greif, Avner. 2006. Institutions and the Path to the Modern Economy: Lessons from Medieval Trade. Cambridge: Cambridge University Press.

Khalilieh, Hassan S . 2006. "Legal Aspects from a Cairo Geniza Responsum on the Islamic Law of the Sea: Practice and Theory." The Jewish Quarterly Review, Vol. 96, No. 2, pp. 180-202.

Stillman, Norman Arthur. 1970. "East-West Relations in the Islamic Mediterranean in the Early Eleventh Century." Ph.D. diss, University of Pennsylvania.

Stillman, Norman Arthur. 1973. "The Eleventh Century Merchant House of Ibn 'Awkal (a Geniza Study)." Journal of the economic and social history of the Orient, 16(1), pp. 15-88.

Stillman, Norman Arthur. 1974. "A Case of Labor Problems in Medieval Egypt." International journal of Middle East studies, 5(2), pp. 194-201. 